\title{
Total Service Quality Measurement in Technical Education System - A Case Study of Deemed University
}

\author{
Ajay Kumar Behera. \\ Mechanical \\ Engg.Deptt.Research scholar \\ SOA University, Bhubaneswar, \\ INDIA.
}

\author{
Narayan C. Nayak, PhD. \\ Mechanical Engg.Deptt, IGIT, \\ Sarang, INDIA
}

\author{
Harish C. Das, PhD. \\ Mechanical Engg.Deptt.SOA \\ University, Bhubaneswar,
}

\begin{abstract}
The purpose of this paper was to investigate expectations of students' perceptions of service quality and students' satisfaction, using both qualitative and quantitative research methods. The service quality model (SERVQUAL) was used in a higher education setting in XYZ University by determining the difference in opinion existed in students' expectations versus their actual experiences. The study examined the relationships within four schools of XYZ University. The researcher tested the relationships between gap score, overall service quality and overall satisfaction. Six in - depth interviews were undertaken and 126 students were surveyed online as part of this research. Expectations of students were related to six factors, such as, physical evidence, contact personnel, reputation, facility/entertainment offer, curriculum and special services. Assurance, knowledgeable, responsive, on time delivering, error free record keeping and caring are the other factors students expected from the University. The widest gap between students' perceived performance and expectations was in the area of reliability. University is not doing fare with regard to its physical facilities, helping students, providing prompt service and understanding students' specific needs. Most students' expectations were only just met. Service quality is more or less similar across the four schools of the University. There are significant relationships across the service gap scores, overall service quality and overall satisfaction. The increased level of service quality and satisfaction has a correlation with the gap scores. In other words, mismatch between student expectation and perceived level of service quality received has an impact upon overall service quality and student satisfaction.
\end{abstract}

Keywords- service quality, supply chain, gap score, expectation, satisfaction, relationship.

\section{INTRODUCTION}

Manufacturing, agriculture and service, in particular, education, are the major economic activities in any country. In India, manufacturing and services together constitute nearly $75 \%$ of the GDP. Moreover, in recent years the growth in GDP is primarily due to the growth in these sectors of the economy [3]. During the last ten years, the share of services in the GDP has grown steadily from about $40 \%$ to about $51 \%$. The Union Government began taxing three services in 1994-95. This has grown steadily and as of 2004-05 the number of services taxed has gone up to 71. All these indicate the growing importance of services in the Indian economy and the need to apply management practices to plan and control operations in the service sector [9].

Service organizations respond to the requirements of customers to satisfy some needs and leave certain experiences in the minds of the customer through a service delivery system [11]. This course addresses the strategic and operational aspects of managing service systems. In addition to discussing the design and operational control of service operations, specific issues pertaining to certain sectors of the service industry are addressed. Such a research is designed to be applied in various service sectors like technical education, banking, hospitality, healthcare, IT, BPO to assess the status of service management practices in his/her organization [2]. The programme is aimed at enabling practitioners to design a systematic stage-wise plan for implementing effective service management practices in their respective segment. This programme intends to deliver an implementation based approach towards service management in an organization [10].

\section{REVIEW OF LITERATURE}

Literature review provides the theoretical basis of the research, supported by relevant literature, concepts and instruments of service quality. Quality is the level of achievement of a product or service by which a customer gets satisfied [17]. Quality of a product can be quantified by measuring number of defects contained in it or by its durability. However, it is difficult to measure quality of a service as it involves human behavior [15]. This research tested the relationships between gap score, overall service quality and overall satisfaction of XYZ University which is one of the prestigious institutes of state Odisha, India [7].

The objective for this literature review was to achieve an understanding of service quality and to combine the marketing service with higher education, in particular to link the measurement of service quality to education institutions [6]. This study focuses on the customer's expectations and perceptions as a measure of potential satisfaction and long term perceptions of quality in an university.

Five determinants with 22 statements were summarized from the original 10 which are used by customers in judging service quality [16], namely:

i) Reliability: ability to perform the promised service dependably and accurately

ii) Responsiveness: willingness to help customers and provide prompt service

iii) Empathy: caring, individualized attention the firm provides its customers

iv) Assurance: knowledge and courtesy of employees and their ability to convey Trust and confidence

v) Tangibles: appearance of physical facilities, equipment, personnel, and communication materials. 


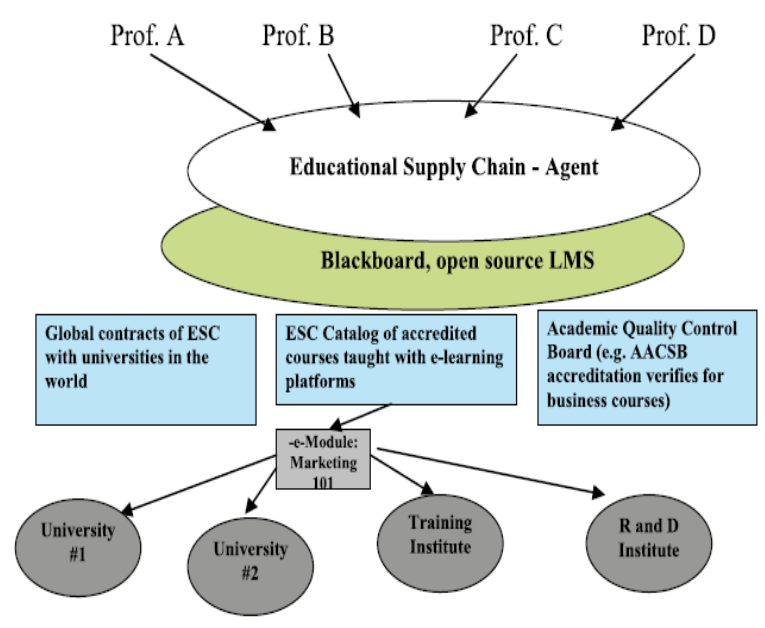

Figure 1. The Educational supply chain system-concept

\section{RESEARCH METHODOLOGY}

This research uses the SERVQUAL service quality gap model to measure graduate students' perceptions of service quality and satisfaction [13]. Qualitative research is undertaken before the SERVQUAL questionnaire was administered to investigate expectations on full time $\mathrm{B}$. Tech courses at XYZ University. In order to ascertain the difference between perceived service quality received and the expectations of service quality amongst students at XYZ University, the study adopted the research questions provided in appendix.

\subsection{DATA COLLECTION}

Educational reforms have been taking place for many years in the Odisha as successive governments have encouraged massive expansion of higher education. Because the public purse could not afford the higher cost, from September 1998 students were required to pay a proportion of their own fees. This situation pushed universities towards becoming corporate bodies as they received funding from government but were actively encouraged to seek extra income from commercial activities [5]. As competitions for sources of university financial funding increased, not only concerning funding from government, which tends to be major part of the income of a higher education institution, but in other areas where they obtained financial support. However, recently, higher education institutions have faced further decline in the unit of funding from government so that many universities are struggling to find funding [8]. Many universities plan to raise the tuition fees for domestic undergraduate courses in 2006, thus students are likely to place a stronger focus on the quality of the education that they receive. In order to assess the status of quality in technical education, research data from various sources have been collected.

\subsection{Qualitative Data}

Before the interview, brief introductions on the purpose of the research issues explained and confidentiality of the data was assured [12]. Four questions were answered in this interview:

\subsection{Quantitative Data}

XYZ University is more suited to stratify random sampling rather than other methods. Disproportionate sub-sections were adopted for the population size of each course is different [9]. About 16 courses were selected by stratified sampling, which represent about 606 full time students, the total students being
1364. A total of 126 questionnaires were received (Table-1) and the response rate was $21 \%$, compared with previous research studies.

TABLE 1: TARGET SAMPLE FOR SURVEY RESEARCH

\begin{tabular}{|c|c|c|}
\hline SCHOOL & TITLE & STUDENTS \\
\hline \multirow[t]{6}{*}{ SOM } & Marketing & 40 \\
\hline & HR & 36 \\
\hline & Finanace & 35 \\
\hline & Systems & 30 \\
\hline & PGDBA & 35 \\
\hline & $\mathrm{BBA}$ & 35 \\
\hline \multirow[t]{2}{*}{ SCA } & $\mathrm{BCA}$ & 40 \\
\hline & MCA & 35 \\
\hline \multirow[t]{7}{*}{ SOT } & Mechanical Engg & 40 \\
\hline & Electrical Engg & 40 \\
\hline & E \& T Engg & 35 \\
\hline & Computer Science Engg & 40 \\
\hline & IT & 40 \\
\hline & EEE Engg & 45 \\
\hline & Civil Engg & 40 \\
\hline \multirow[t]{2}{*}{ SOL } & & 40 \\
\hline & Total $=4$ Schools & 606 \\
\hline
\end{tabular}
Technology, SOL $=$ School of Law

\subsection{Questionnaire Design: The SERVQUAL Instrument}

The questionnaire based on SERVQUAL was used in this study to measure students' expectations and perceptions of service quality (see Appendix B). The five dimensions included in the questionnaire are: tangibles, reliability, responsiveness, assurance, empathy [1]. The above dimensions were grouped as mentioned below:

i) Tangibility, including question 1 to question 4

ii) Reliability, including question 5 to question 9

iii) Responsiveness, including question 10 to question 13

iv) Assurance, including question 14 to 16

v) Empathy, including question 17 to 20

\section{DATA ANALYSIS}

Questionnaire data were transformed into 'difference' quality scores. For each item, different quality scores were calculated based on the difference between the student's perceived quality of service and the expectations that they had from the service, represented as:

Service Quality = perceived quality of service - expectations of service quality.

i. service quality exceeded expectations where perceptions expectations $>0$. Expectations exceeded means 'Quality surprise'

ii. service quality received met expectations where perceptions - expectations $=0$. Expectations met means 'Satisfactory'

iii. Service quality received did not exceed or meet expectations where perceptions - expectations $<0$. Expectations not met means 'Unacceptable Quality'.

The original expectation of the students before arrival at University was assessed through an in-depth interview (Table2). Most respondents have expectations about the course provided by the university: whether the course links to practice or covers all aspects of the subject. Student A, looking for a project which can link to a real - Life Company. So, this 
University is the best choice. Students B and C assumed the course to be comprehensive and would be covered. Student D expected the curriculum to be average. Student E and F expected the course to be close to practice and it has a good relationship with industry.

\section{TABLE 2: IN - DEPTH INTERVIEW SAMPLE FRAME}

\begin{tabular}{|l|l|l|l|l|}
\hline $\begin{array}{l}\text { Identificatio } \\
\text { n No. }\end{array}$ & Occupation & Gender & School & Region \\
\hline & Student A & Male & SCA & MADRAS \\
\hline 2 & Student B & Female & SOL & $\begin{array}{l}\text { GUJARA } \\
\text { T }\end{array}$ \\
\hline 3 & Student C & Male & SOL & BIHAR \\
\hline 4 & Student D & Female & SCA & ASSAM \\
\hline 5 & Student E & Male & SOT & BOMBAY \\
\hline 6 & Student F & Male & SOT & ORISSA \\
\hline
\end{tabular}

The overall measure of service quality in the form of an average score was made by the SERVQUAL instrument SPSS version 13 through which several tests and analysis were carried out (Table-3), to analyze the consistency for all the research dimensions .

\begin{tabular}{|l|l|}
\hline \multicolumn{1}{|c|}{ Test Topic } & \multicolumn{1}{|c|}{ Statistic Test } \\
\hline Average mean of expectations & Descriptive statistics \\
\hline $\begin{array}{l}\text { Means for expectation, perception and gap } \\
\text { score }\end{array}$ & Descriptive statistics \\
\hline $\begin{array}{l}\text { Compare the whether they are significant } \\
\text { difference between expectation and perception }\end{array}$ & T-Test \\
\hline $\begin{array}{l}\text { Comparison of school } \\
\text { classification }\end{array}$ & One Way ANOVA \\
\hline $\begin{array}{l}\text { Correlation among gap scores, overall service } \\
\text { quality and satisfaction }\end{array}$ & $\begin{array}{l}\text { Pearson product } \\
\text { moment correlation }\end{array}$ \\
\hline $\begin{array}{l}\text { Linear Relationship among scores, } \\
\text { overall service quality and satisfaction }\end{array}$ & Regression analysis \\
\hline
\end{tabular}

\section{TABLE 3: RELIABILITY ANALYSIS -SCALE TEST}

Table 4 shows the demographic characteristics of gender, age group, school, and states. In the sample, for the School of Technology has the largest number of respondents and the School of Law has at least one.

\section{TABLE 4: DEMOGRAPHIC CHARACTERISTICS OF THE RESPONDENTS}

\begin{tabular}{|l|l|l|l|l|l|}
\hline School & $\begin{array}{l}\text { Numbe } \\
\mathbf{r}\end{array}$ & $\begin{array}{l}\text { Percentag } \\
\text { e }\end{array}$ & Region & $\begin{array}{l}\text { Numbe } \\
\mathbf{r}\end{array}$ & $\begin{array}{l}\text { Percentag } \\
\text { e }\end{array}$ \\
\hline SOM & 30 & $24 \%$ & ORISSA & 35 & $27 \%$ \\
\hline SCA & 29 & $23 \%$ & DELHI & 2 & $2 \%$ \\
\hline SOT & 54 & $43 \%$ & GUJRAT & 6 & $5 \%$ \\
\hline SOL & 13 & $10 \%$ & W.B & 5 & $4 \%$ \\
\hline $\begin{array}{l}\text { TOTA } \\
\text { L }\end{array}$ & 126 & $100 \%$ & M.P & 4 & $4 \%$ \\
\hline & & & ASSAM & 2 & $3 \%$ \\
\hline $\begin{array}{l}\text { Gender } \\
:\end{array}$ & & & $\begin{array}{l}\text { MUMBA } \\
\text { I }\end{array}$ & 3 & $2 \%$ \\
\hline Male & 90 & & U.P & 5 & $4 \%$ \\
\hline Female & 36 & & A.P & 2 & $2 \%$ \\
\hline Total: & 126 & & $\begin{array}{l}\text { CHENNA } \\
\text { I }\end{array}$ & 10 & $8 \%$ \\
\hline & & BIHAR & 35 & $28 \%$ \\
\hline & & & OTHERS & 17 & $13 \%$ \\
\hline
\end{tabular}

Internal consistency reliability was calculated using the subprogram of SPSS 'Reliability' to perform an item response analysis for both expectations and perceptions for each dimension (Table-5). The $\alpha$-coefficient close to 1 signifies more reliability. The total $\alpha$ of 0.9 indicates that the five dimensions of SERVQUAL are highly internally reliable (Nunnally). The Cronbach' alpha for service quality dimensions range between 0.684 to 0.837 . Thus the scales used to measure the various aspects of service quality have been regarded as reliable.

\section{TABLE 5: RELIABILITY ANALYSIS OF VARIOUS} RESEARCH ISSUES

\begin{tabular}{|l|l|l|l|l|l|}
\hline \multicolumn{6}{|l|}{ Reliability analysis - Scale (ALPHA) } \\
\hline $\begin{array}{l}\text { Reliabilit } \\
\text { y }\end{array}$ & $\begin{array}{l}\text { Responsivene } \\
\text { ss }\end{array}$ & $\begin{array}{l}\text { Assuranc } \\
\text { e }\end{array}$ & $\begin{array}{l}\text { Empath } \\
\text { y }\end{array}$ & $\begin{array}{l}\text { Tangibilit } \\
\text { y }\end{array}$ & $\begin{array}{l}\text { Tota } \\
1\end{array}$ \\
\hline 0.837 & 0.781 & 0.780 & 0.688 & 0.684 & $\begin{array}{l}0.90 \\
9\end{array}$ \\
\hline
\end{tabular}

The expectations that students had, ranked the importance level across various dimensions: Tangibility, Reliability, Responsiveness, Assurance, and Empathy (Table 6). The Assurance dimension was regarded by nearly half of the respondents and ranked ' 1 ' as the most important, followed by Responsiveness, Empathy, Reliability, and Tangibility. Tangibility, with over $50 \%$ of the respondents, was considered to be the least important of the dimensions of service quality expected.

The results in Table- 6 were quite similar with the ranking of the each dimension by the average mean of expectations (Table VII). The descriptive statistics for each SERVQUAL dimension is Assurance (7.81), mostly expected by students, and followed by Reliability (7.78), Empathy (7.72), Responsiveness (7.62) and Tangibility (7.20). The most expected aspects of service by respondents are 'Employees of universities will have the appropriate knowledge to answer student questions', 'Employees of universities will always be willing to help students', 'University will deliver its services on time', 'University insist on error free records', and 'When students have problems, universities will show a sincere interest in understanding the problem and resolving it'. All the above received the highest expectation scores compared to the other items.

TABLE 6: IMPORTANCE OF RESEARCH DIMENSIONS

\begin{tabular}{|l|c|c|c|c|c|}
\hline RANKING & 1 & 2 & 3 & 4 & 5 \\
DIMENSION & & & & & \\
\hline Tangibility & $8.46 \%$ & $5.09 \%$ & $13.4 \%$ & $22.04 \%$ & $50.84 \%$ \\
\hline Reliability & $13.55 \%$ & $16.2 \%$ & $22.87 \%$ & $33.8 \%$ & $13.55 \%$ \\
\hline Responsiveness & $18.6 \%$ & $35.6 \%$ & $26.27 \%$ & $12.7 \%$ & $6.77 \%$ \\
\hline Assurance & $42.38 \%$ & $24.57 \%$ & $16.85 \%$ & $11.03 \%$ & $5.08 \%$ \\
\hline Empathy & $16.91 \%$ & $18.65 \%$ & $20.35 \%$ & $20.35 \%$ & $23.74 \%$ \\
\hline
\end{tabular}


Table-7: Means For Expectations, Perceptions and Gap Score for SERVQUAL (N=126)

\begin{tabular}{|c|c|c|c|c|c|c|c|c|}
\hline \multicolumn{2}{|c|}{ DESCRIPTIVE STATISTICS } & \multicolumn{2}{|c|}{$\begin{array}{l}\text { EXPECTATIONS } \\
\text { OF LU }\end{array}$} & \multicolumn{2}{|c|}{$\begin{array}{c}\text { PERCEPTIONS } \\
\text { OF KU }\end{array}$} & \multicolumn{2}{|c|}{ GAP SCORE } & \multirow{2}{*}{$\begin{array}{c}\begin{array}{c}\text { DIFFE- } \\
\text { RENCE }\end{array} \\
\text { SIG }\end{array}$} \\
\hline Dimension & Statement & $\mathrm{M}$ & SD & $\mathrm{M}$ & SD & M & SD & \\
\hline \multirow[t]{5}{*}{ TANGIBLE } & & 7.2 & 1.79 & 6.48 & 1.61 & $\begin{array}{l}-0.71 \\
\end{array}$ & 1.09 & \\
\hline & Question-1 & 7.75 & 1.3 & 6.5 & 1.52 & -1.25 & 1.57 & 0 \\
\hline & Question-2 & 7.63 & 1.32 & 6.01 & 1.8 & -1.62 & 2.23 & 0 \\
\hline & Question-3 & 5.54 & 2 & 6.38 & 1.45 & 0.84 & 1.79 & 0 \\
\hline & Question-4 & 7.81 & 1.43 & 7.02 & 1.52 & -0.79 & 1.63 & 0 \\
\hline \multirow[t]{6}{*}{ RELIABILTY } & & 7.78 & 1.43 & 6.78 & 1.6 & -1 & 0.24 & \\
\hline & Question-5 & 7.82 & 1.6 & 6.43 & 1.65 & -1.39 & 1.87 & 0 \\
\hline & Question-6 & 7.9 & 1.43 & 6.8 & 1.75 & -1.1 & 1.91 & 0 \\
\hline & Question-7 & 7.37 & 1.49 & 6.53 & 1.4 & -0.87 & 1.46 & 0 \\
\hline & Question-8 & 7.9 & 1.27 & 7.03 & 1.44 & -0.87 & 1.46 & 0 \\
\hline & Question-9 & 7.91 & 1.27 & 7.11 & 1.62 & -0.8 & 1.53 & 0 \\
\hline \multirow[t]{5}{*}{ RESPONSIVENESS } & & 7.62 & 1.43 & 6.97 & 1.55 & -0.65 & 0.14 & \\
\hline & Question-10 & 7.51 & 1.46 & 6.71 & 1.58 & -0.8 & 1.54 & 0 \\
\hline & Question-11 & 7.73 & 1.19 & 6.96 & 1.34 & -0.77 & 1.52 & 0 \\
\hline & Question-12 & 8.09 & 1.15 & 7.6 & 1.4 & -0.49 & 1.5 & 0 \\
\hline & Question-13 & 7.18 & 1.72 & 6.59 & 1.69 & -0.6 & 1.79 & 0 \\
\hline \multirow[t]{4}{*}{ ASSURANCE } & & 7.81 & 1.38 & 7.22 & 1.48 & -0.6 & 0.47 & \\
\hline & Question-14 & 7.66 & 1.44 & 6.9 & 1.59 & -0.76 & 1.42 & 0 \\
\hline & Question-15 & 7.48 & 1.42 & 7.41 & 1.44 & -0.07 & 1.03 & 0.488 \\
\hline & Question-16 & 8.3 & 1.12 & 7.32 & 1.37 & -0.98 & 1.4 & 0 \\
\hline \multirow[t]{5}{*}{ EMPATHY } & & 7.72 & 1.35 & 6.89 & 1.61 & -0.83 & 0.24 & \\
\hline & Question-17 & 7.58 & 1.54 & 7.05 & 1.54 & -0.83 & 1.54 & 0 \\
\hline & Question-18 & 7.8 & 1.48 & 6.99 & 1.7 & -0.81 & 1.92 & 0 \\
\hline & Question-19 & 7.74 & 1.1 & 6.62 & 1.64 & -1.12 & 1.78 & 0 \\
\hline & Question-20 & 7.7 & 1.1 & 6.62 & 1.64 & -1.08 & 1.78 & 0 \\
\hline TOTAL & & 7.6 & 1.5 & 6.87 & 1.59 & -0.75 & 0.96 & 0 \\
\hline
\end{tabular}

\section{CONCLUSIONS}

The results were from both qualitative and quantitative research. From this research students' general expectations were explored, and Assurance is the most significant dimension students of student expectations . Students are generally satisfied with the quality of the service they received. However, there are some aspects, such as physical facilities, helping students, or providing prompt service are where they were not .The service quality levels of four schools within XYZ University are more or less similar. There are significant positive relationships between gap score; overall service quality and overall satisfaction. The increasing level of overall service quality and satisfaction can be predicted by the extent of the gap scores increase.

\subsection{LIMITATIONS}

This study has limited generalizability because it was conducted in a single time period, with a limited number of XYZ students. It is difficult to generalize across the whole XYZ student base as a result and the results are certainly not transferable in higher education more generally.

The two major limitations for this research are the use of the SERVQUAL instrument in the field of education to evaluate the service quality of University and the internal restrictions of the SERVQUAL instrument However, they concluded that SERVQUAL can be adapted to match the characteristics or specific research needs of a particular service organization (Parasuraman et al.)[15]. In the education settings, the collective finding of various studies regarding the use of SERVQUAL offers support for the validity, reliability, and predictive validity of the scale However, the original five dimensions could be regarded as incompatible with education institutions. The disputes regarding the SERVQUAL as a useful tool generally assesses service quality in education have been debated by many researchers. Studies in higher education testing the construct of the instrument have been limited. This study was performed as an overall assessment of student satisfaction at XYZ University. However, a student's experience in the university is influenced by other services in some aspects; it could be outside of the University such as admissions, registry, and student life. Although this limitation does not significantly impact on the importance of an overall assessment of satisfaction, the study of service quality by service programs and units may complement an overall assessment. The quality of online questionnaires depends upon respondents' willingness to answer the items openly and candidly. There are difficulties in proving these conditions were met or not and so it is difficult to 
tell how truthful the respondents' answers were. Finally, the sample size is relatively small for the School of Management proportion of the respondents and future studies would need to increase this

\subsection{SCOPE FOR FUTURE RESEARCH}

This research investigated the student satisfaction and expectations and there is a correlation in existence between perceived service quality and student satisfaction.

i) Analyze perceived service quality differences by customer's past experience, family income, sex, educational level, and more dependent variables that give more information for predicting service quality and customer satisfaction.

ii) The relationships between student behaviours and their satisfaction for XYZ University could be assessed using a similar online questionnaire methodology although the questionnaire would need to be amended.

iii) Some aspects of education quality, excluded in this study such as course, student life, and reputation of XYZ University, could be evaluated in future. Research could investigate how attributes of service quality vary from academic department to non-academic department.

Note: The authors have made commitment with University not to disclose the name and affiliation of the University. However, same is available with the authors. Informations collected were treated confidential and used solely for academic research purposes.

\section{REFERENCES}

[1]. Abdullah, F. (2005). HEdPERF versus SERVPERF: The Quest for ideal measuring instrument of service quality in higher education sector, Quality Assurance in Education, vol.13, no.4, pp.305-328.

[2]. Carol J. R. and Manoj K. M. (2005). Defining the concept of supply chain quality management and its relevance to academic and industrial practice. Int. J. Production Economics, 96, pp. 315-337.

[3]. Christoph T., Herbert K. and David B. G. Improving the execution of supply chain management in organizations. Int. J. Production Economics (press).

[4]. Cronin, J.J and Taylor, S.A. (1994). SERVPERF versus SERVQUAL: Reconciling Performance-based and Perceptions-minus-Expectations Measurement of Service Quality, Journal of Marketing, vol. 58, pp. 125-131.

[5]. Hale K. and Janet L. H. (2008). A replication and extension of quality management into the supply chain. Journal of Operations Management, 26, pp. 468-489.

[6]. Jensen, J.B. and Markland, R.E. (1996). Improving the Application of Quality Conformance Tools in Service Firms, The Journal of Services Marketing, vol.10, no.1, pp.35-55.

[7]. Gronroos, C., (1998). Service quality: the six criteria of good perceived service quality, Review of Business, vol.9, no. 3 , pp 10-13.

[8]. Gunasekaran, A., Ngai, E.W.T. (2005). Build-to-order supply chain management: a literature review and framework for development. Journal of Operations Management, 23, pp. 423-451.
[9]. Gustafsson, A., Nilsson, L. and Johnson, M. D. (2003). The role of quality practices in service organizations, International Journal of Service Industry Management, vol.14, no. 2, pp. 232-244.

[10].Jian C., Xiangdong L., Zhihui X. and Jin L. (2009). Improving supply chain performance management: A systematic approach to analyzing iterative KPI accomplishment. Decision Support Systems, 46, pp. 512521.

[11].Jorn-Henrik T. and Daniel H. (2011). An empirical analysis of supply chain risk management in the German automotive industry. Int. J. Production Economics, 131, pp. 242-249.

[12]. Miguel A. L. and Nevena Y, (2005). On characterizing the 4 C's in supply chain management, Journal of Operations Management, 23, pp. 81-100.

[13]. Parasuraman, A (2002). Service Quality and Productivity: A Synergistic Perspective, Managing Service Quality, vol.12, no.1, pp.6-9.

[14]. Parasuraman, A., Berry, L.L. and Zeithaml, V. A. (1991). Refinement and Reassessment of the SERVQUAL Scale, Journal of Retailing, vol.67, no. 4, pp. 420-450.

[15]. Parasuraman, A., Zeithaml, V. A. and Berry, L.L. (1988). SERVQUAL: A Multiple-item Scale for Measuring Customer Perceptions of Service Quality, Journal of Retailing, vol. 64, no. 1, pp. 12-37.

[16]. Parasuraman, A., Zeithaml, V. A. and Berry, L.L. (1985). A Conceptual Model of Service Quality and its Implication for Future Research, Journal of Marketing, vol. 49, pp. 4150 .

[17]. S. Thomas F. Jr. (2008). Towards an understanding of supply chain quality management. Journal of Operations Management, 26, pp. 461-467.

\section{Appendix $A$}

\section{APPENDIX}

This section tries to assess the expectation of an individual student before admitting XYZ University. It contains four questions.

Question 1 asked why students choose XYZ University. Question 2 asked what expectations student had before they came to XYZ ?

Question 3 asked why did they have these expectations?

Question 4 asked are they satisfied, from a service quality perspective? If yes, why? If no, why?.

\section{Appendix $B$}

\section{XYZ University Service Quality Questionnaire}

This research is intended to provide XYZ University with an understanding of quality of its service. The research contains two parts: part 1 and 2. Part 1 tests student expectations of leading Universities in general and XYZ University in particular and Part II assess overall quality and satisfaction toward XYZ University. Someone may make his/her opinion in $10-15$ minutes.

Please enter your student registration number in the space provided and it is a 6 digit code that you can find just above the bar code on your student ID card. By 
entering the registration number, a cross reference to responses can be made with profile data supplied by the university registry: gender, school \& course, nationality and domicile. We will not, at any stage, be given access to more personal details such as your name, address, email, telephone number, etc. This will ensure that this information cannot be used inappropriately and your responses will not be attributable to you personally.

\section{Part I: Perceptions of Leading Universities in General and XYZ} University in Particular

There are 20 questions in this part applicable to XYZ University. Based on your experience as a student, please think about the kind of University that would deliver an excellent quality of educational service. Think about the kind of University at which you would be pleased to study. Please show the extent to which you think such a University would possess the features described by each statement. If you feel a feature is not at all essential for leading University, write ' 1 ', strongly disagree. If you feel a feature is absolutely essential for an leading University, write ' 9 ', strongly agree. There is no right or wrong answers. We are more interested in what truly reflects in your feelings regarding the University that would deliver an excellent quality of service.

\section{Question 1}

University has up-to-date appropriate equipment in comparison to leading university.

Strongly Disagree 123456789 Strongly Agree

\section{Question 2}

University's physical facilities, such as the accommodation are well designed for their use in comparison to leading university

Strongly Disagree 1223456789 Strongly Agree

\section{Question 3}

University's employees are neat and professionally dressed in comparison to leading university.

Strongly Disagree 1223456789 Strongly Agree

\section{Question 4}

Materials associated with the service (such as course packs or brochures) are informative and easy to read at XYZ University in comparison to leading university .

Strongly Disagree 11233456789 Strongly Agree

\section{Question 5}

When XYZ University promises to do something by a certain time, it does it in comparison to leading university.

Strongly Disagree 123456789 Strongly Agree

\section{Question 6}

When you have a problem, XYZ University shows a sincere interest in understanding the problem and resolving it in comparison to leading university.

Strongly Disagree 1233456789 Strongly Agree

\section{Question 7}

University performs the service such as teaching, students' requests right the first time in comparison to leading university.

Strongly Disagree 1223456789 Strongly Agree

\section{Question 8}

University delivers its services on time in comparison to leading university.

Strongly Disagree 1223456789 Strongly Agree

\section{Question 9}

University insists on error free records, such as results of exams etc in comparison to leading university.

Strongly Disagree 1223456789 Strongly Agree

\section{Question 10}

Employees tell you exactly when a service will be performed in comparison to leading university.

Strongly Disagree 1223456789 Strongly Agree

\section{Question 11}

Employees give you prompt service in comparison to leading university.

Strongly Disagree 1223456789 Strongly Agree Question 12

Employees are always willing to help you in comparison to leading university.

Strongly Disagree 123456789 Strongly Agree Question 13

Employees are never being too busy to respond to your requests in comparison to leading university.

Strongly Disagree 1223456789 Strongly Agree

\section{Question 14}

The behaviour of employees of XYZ University instills confidence in students in comparison to leading university.

Strongly Disagree 1223456789 Strongly Agree Question 15

Employees are consistently courteous with you in comparison to leading university.

Strongly Disagree 1223456789 Strongly Agree

\section{Question 16}

Employees have the appropriate knowledge to answer student Questions in comparison to leading university.

Strongly Disagree 1223456789 Strongly Agree

\section{Question 17}

University gives you individual attention in comparison to leading university.

Strongly Disagree 1223456789 Strongly Agree

\section{Question 18}

University has operating hours convenient to their students in comparison to leading university.

Strongly Disagree 112334556789 Strongly Agree

\section{Question 19}

University has your best interests at heart in comparison to leading university.

Strongly Disagree 1223456789 Strongly Agree Question 20

The employees of XYZ University understand your specific needs in comparison to leading university.

Strongly Disagree 1233456789 Strongly Agree

\section{Part II: Overall Quality of Service at XYZ University}

\section{Question 21}

How would you rate the overall quality of service provided by University?

Extremely Poor 1233456789 Extremely Good

\section{Question 22}

Thinking about XYZ University's service overall, please rate the value you feel you get for your money.

Poor Value $1 \begin{array}{llllllllll}1 & 2 & 3 & 4 & 5 & 6 & 7 & 8 & 9 & \text { Excellent Value }\end{array}$

\section{Question 23}

Overall, how satisfied are you with XYZ University?

Very Dissatisfied $1 \begin{array}{lllllllll}1 & 2 & 3 & 4 & 5 & 6 & 7 & 8 & 9\end{array}$ Very Satisfied

Question 24

Finally, Please rank the following five statements in order of importance from 1-5 (1 being your most important and 5 your 
least important). Each of these statements reflects a general feature of the service provided by XYZ University.

The visual impact of University campus with respect to its accommodation, facilities and surroundings.

University's ability to perform promised services dependably and accurately.

University's willingness to help students and provide a prompt service.

University's staff are knowledgeable, courteous and convey a sense of trust and confidence.

University offers students individual attention and a caring environment. 